\title{
Is Environmental Improvement in Automotive Component Design Highly Constrained?
}

\section{An Instrument Panel Case Study}

Gregory A. Keoleian

National Pollution Prevention Center for Higher Education

School of Natural Resources and Environment

University of Michigan, Ann Arbor, MI, USA

\section{Keywords}

automotive component design environmental improvement instrument panel life-cycle design multiobjective decisionmaking system analysis

\author{
Address correspondence to: \\ Gregory A. Keoleian \\ National Pollution Prevention Center for \\ Higher Education \\ School of Natural Resources and \\ Environment \\ University of Michigan \\ Ann Arbor, MI 48109-1115 USA \\ gregak@umich.edu \\ http://www.umich.edu/-nppcpub/
}

C) Copyright 1998 by the Massachusetts Institure of Technology and Yale University

\section{Summary}

This article investigates the influence of environmental, cost, and performance requirements on the design and management of automotive components through a case study involving instrument panels. To address the question of whether the environmental improvement of an instrument panel (IP) is highly constrained, a life-cycle inventory analysis is used to characterize the major environmental burdens associated with a generic IP defined from an average of three midsized vehicle models. A life-cycle cost analysis is also conducted to understand the market forces operating in the domains of the original equipment manufacturer, consumer, and end-of-life (EOL) vehicle managers. This study indicates that the existing set of environmental requirements, in conjunction with current cost drivers and the large set of manufacturing and use phase functional performance requirements, highly constrain opportunities for environmental improvement. Specific improvement strategies-lightweighting, elimination of the painting operation, and reduction in material complexity-are examined in the context of existing system requirements. The near-term forecast for improvements is not optimistic. Innovation will continue in a slow and piecemeal fashion until requirements affecting the total vehicle system are significantly changed. 


\section{Introduction}

The automobile is a resource-intensive mode of personal transportation with significant lifecycle environmental burdens and impacts (Keoleian et al. 1997; Graedel and Allenby 1998). The automobile life cycle encompasses materials production, manufacturing, use, and end-of-life (EOL) vehicle management, which includes dismantling, shredding, recycling, and landfill disposal. Environmental improvement of this life cycle is governed by a complex set of performance, cost, regulatory, policy, aesthetic, and environmental requirements. These system requirements are controlled by the key stakeholders that influence the automobile life cycle, including: material, part and equipment suppliers, original equipment manufacturers (OEMs), consumers, regulators, and dismantlers and shredders. In essence, these stakeholders are responsible for the life-cycle management of the automobile, which has been defined as "all decisions and actions taken by multiple stakeholders which ultimately determine the environmental profile and sustainability of the product system" (Keoleian et al. 1995, 18).

The U.S. Environmental Protection Agency (U.S. EPA) Common Sense Initiative (CSI) is a recent program launched to explore innovative methods for achieving environmental improvement through a multi-stakeholder process. The "cleaner, cheaper, smarter" theme of the CSI seeks to develop industry-specific policies that enable companies to respond to environmental goals in a flexible manner and to achieve more effective environmental protection at lower cost. The Automotive Life-Cycle Management/ Supplier Partnership (LCM/SP) project of CSI provided a mechanism to apply the cleaner, cheaper, smarter theme to automotive design and management.

This article examines system parameters and requirements that influence the environmental improvement of an instrument panel (IP) that was selected for a pilot project by the LCM/SP team. The IP is a complex automotive component consisting of multiple materials. Life-cycle inventory analysis (LCI) (SETAC 1993a; Vigon et al. 1993) and the life-cycle design framework (Keoleian and Menerey 1993; Keoleian et al.
1995) were used to characterize the environmental profile of the IP and the conflicts among system requirements that shape this profile. Incremental improvements to the automobile often occur through design changes to individual parts or components. Factors affecting environmental improvement of automobiles have been widely studied (e.g., National Research Council 1992; DeCicco and Delucchi 1997). Multiobjective analysis of performance, cost, regulatory, and environmental issues at the fundamental level of individual automotive part or component, however, is a relatively new area of research. Harsch and colleagues (1997) have studied environmental, economic, and technical factors for automobile painting processes, although regulatory issues were not addressed. An earlier study by the author analyzed the full set of requirements for an oil filter, but the inventory analysis was limited to energy consumption (Keoleian 1995a).

The primary objectives of this article are to characterize the key factors and issues influencing the design and management of the IP product system, and to assess what constraints these factors impose on the improvement of the IP's environmental performance. Specific environmental improvement strategies are examined in the context of system requirements to determine which requirements are currently more controlling and which need to be strengthened to provide greater incentives for driving improvement.

\section{Methodology}

Two fundamental elements of life-cycle design and management were addressed in this investigation: (1) identification of system requirements, and (2) the design analysis of both the existing IP product system and potential strategies for its improvement. The multicriteria requirements matrices proposed in the U.S. EPA life-cycle design framework (Keoleian and Menerey 1993; Keoleian et al. 1995; Keoleian 1995b) were used to identify and organize key performance and regulatory/policy requirements for the IP system. Life-cycle inventory analysis was used to characterize the environmental profile of the IP system. The LCI was conducted following the guidelines recommended by the U.S. 
EPA and the Society of Environmental Toxicology and Chemistry (SETAC) (Vigon et al. 1993; SETAC 1993a). The design analysis of the IP system also included a preliminary life-cycle cost analysis. Strategies for IP design improvement were proposed by considering the generalized set of product system design strategies developed as part of the U.S. EPA life-cycle design framework (see table 4.5 in Keoleian et al. 1995 or table 6.9 in Curran 1996). The roles of policy, economics, and consumer behavior in shaping the total vehicle system requirements were also analyzed.

\section{Product System Definition and Inventory Scope}

This study evaluated the environmental burdens of a structural instrument panel for a passenger vehicle. Nonstructural components such as air bags, wiring harnesses, and electronic components were excluded. The structural components include the surface components (skins), the substrate and foam parts attached to the skins, ventilation duct components, vent grilles, cross-car beam, and several smaller parts.

For this study, an "average" IP was defined using three midsized U.S. car models: the 1995 Chevrolet Lumina, 1996 Dodge Intrepid, and 1996 Ford Taurus. The material composition of each vehicle's IP was obtained from industry teardown studies, and these composition values were averaged. This "average IP" consisted of 17 different materials ( 15 plastic resins and 2 met- als) and weighed over 49 pounds (lb) or 22 kilograms $(\mathrm{kg})$ as shown in figure 1 . The "average IP" consists of the following materials: acrylontitrile butadiene styrene (ABS), highdensity polyethylene (HDPE), low-density polyethylene (LDPE), nylon, polycarbonate (PC), polycarbonate glass fiber $10 \%$ by weight (PC GF10), PC/ABS blend, polyethylene terephthalate thermoset (PET TS), phenol-formaldehyde thermoset (PF TS), polypropylene (PP), polypropylene glass fiber $30 \%$ by weight (PP GF30), polyphenylene ether (PPE), polyurethane foam (PU), polyvinylchloride (PVC), styrene maleic anhydride (SMA), magnesium, and steel. While steel was the most significant single material by weight, plastic resins were the most common class of materials used in the average IP and comprised $68 \%$ of the total mass. The relative amount of plastics in IPs is much higher than in the total automobile where, in a typical 1995 family vehicle, steel and other metal components constitute approximately $84 \%$ of the total mass (AAMA 1995, 55).

A detailed description of the inventory model equations, data sources, and assumptions has been published previously by the authors (Keoleian and McDaniel 1997; McDaniel 1997). A flow diagram highlighting the major life-cycle processes that were inventoried is shown in figure 2 . The IP inventory analysis is based on a vehicle life of 193,000 kilometers $(\mathrm{km})$ or 120,000 miles. The "use" phase includes the environmental burdens related to transport-

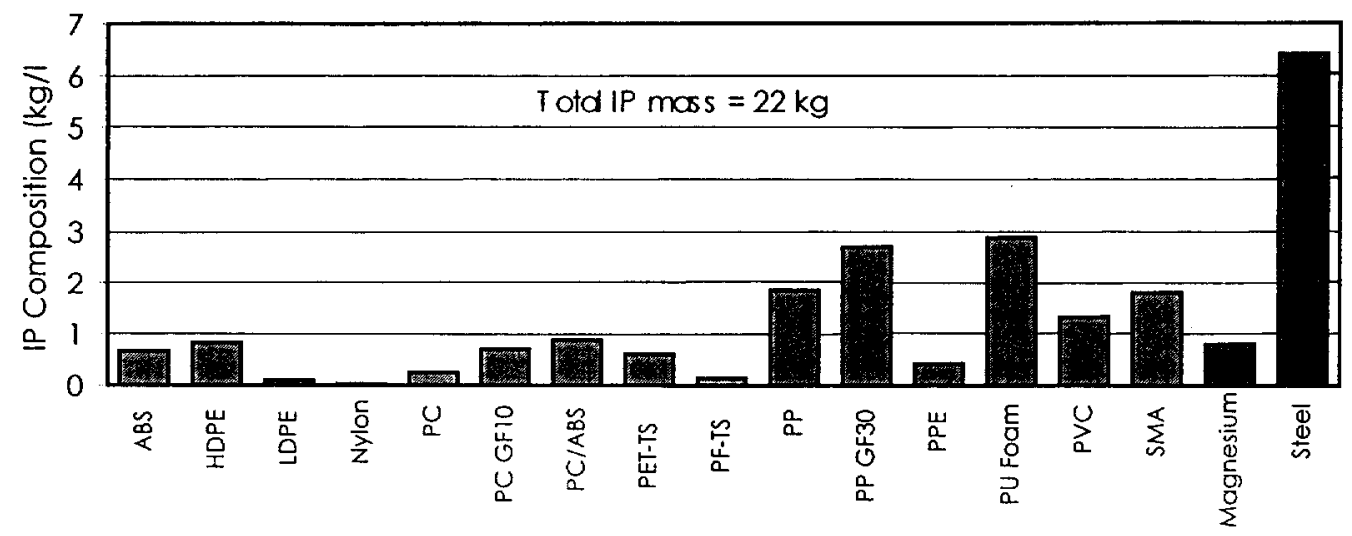

Figure I Material composition of the "average" instrument panel from a midsized vehicle (average of a Chevrolet Lumina, Dodge Intrepid, and Ford Taurus). 


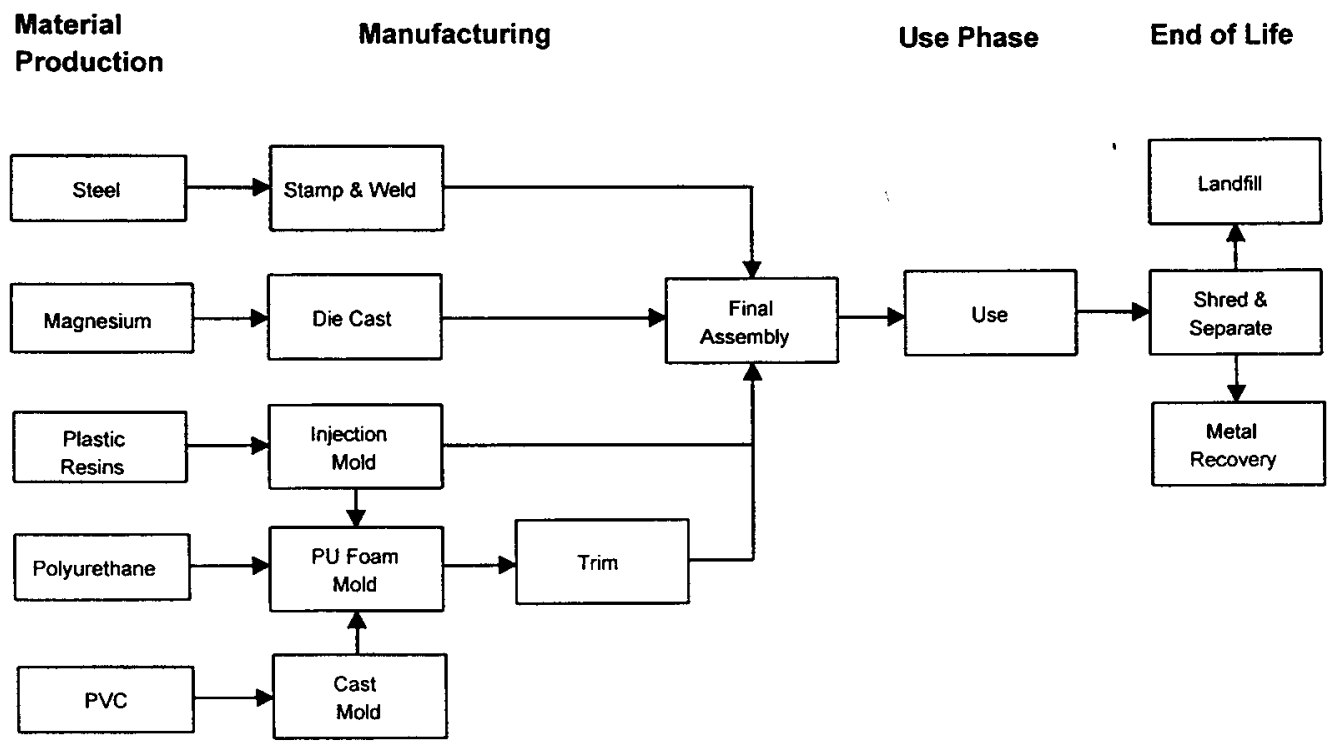

Figure 2 Process flow diagram of the instrument panel life cycle.

ing the IP a distance of $193,000 \mathrm{~km}$ by the "average" vehicle. The fuel economy and vehicle emissions for the Chevrolet Lumina, Dodge Intrepid, and Ford Taurus were averaged. Energy, solid waste, and air and water pollutant emissions associated with precombustion and combustion of gasoline for the "average" vehicle are allocated to the IP on a mass basis (Keoleian and McDaniel 1997). The inventory model for the average IP was developed under data availability and time constraints set by the LCM/SP project. Accordingly, the inventory of the IP product system was based on the following assumptions and limitations:

- Air and water pollutant releases from energy production and transportation processes associated with manufacturing, shredding, and end-of-life phases were inventoried. However, inventories of the pollutant emissions for these phases did not include direct releases from the manufacturing or shredding facilities, except for volatile organic compounds (VOCs).

- Manufacturing process inputs, such as cutting fluids, facility, administrative, and labor inputs were neglected.

- Disposable packaging used for shipping components was neglected. (Most parts are shipped in reusable containers.)

The original inventory analysis (Keoleian and McDaniel 1997; McDaniel 1997) was supplemented with data reported herein that characterize VOC emissions from the IP painting process. Upper limits to VOC emissions for both water-based colorcoat and solvent-based clear/ colorcoat painting processes were estimated using the VOC content of the solvent and a transfer efficiency of 40\% (Farrington 1996).

A life-cycle cost analysis was performed following documented methods (Kar and Keoleian 1996; Keoleian and Kar 1998). Manufacturing costs, gasoline costs allocated to the IP, and the EOL management costs were evaluated. The manufacturing costs of the IP, which were proprietary, were characterized very roughly using replacement part prices. Replacement part prices, however, are marked up significantly relative to original equipment manufacturing costs. In addition to the cost parameters previously cited (Keoleian and Kar 1998), magnesium EOL processing costs were assumed to be the same as aluminum $(\$ 0.22 / \mathrm{kg})$, and the scrap values for automotive scrap steel and magnesium were $\$ 150 /$ metric ton ( $\$ 136 /$ ton) and $\$ 4.25 / \mathrm{kg}$ 
(\$1.93/lb), respectively (American Metal Market 1996).

\section{Multicriteria Analysis}

Successful products must fulfill a wide variety of performance, cost, regulatory, and environmental requirements during their life cycles. $A$ set of these requirements was defined by McDaniel and Keoleian (McDaniel 1997; Keoleian and McDaniel 1997) and organized in a matrix formed by life-cycle stages (manufacturing that included materials production, use/service, and EOL management) and requirement categories (environmental, cost, performance, and regulatory). This matrix set highlights the opportunities for and barriers to improving the product's environmental performance.

In this study, environmental requirements were classified into five main categories:

1. environmental objectives that address life-cycle impacts-characterized by lifecycle impact assessment methodology (U.S. EPA 1995; SETAC 1993b),

2. environmental objectives that address life-cycle inventory burdens-measured by life-cycle inventory methodology (Vigon et al. 1993; SETAC 1993a),

3. environmental objectives related to discrete OEM improvement strategies,

4. the regulatory framework that primarily addresses human and ecological health, and

5. relevant industry standards influencing the systems that primarily address safety.

These categories encompass the range of potential and existing approaches for guiding environmental improvement. The LCA framework that relates to the first two categories is potentially the broadest approach for environmental management, while the other three categories vary in their coverage of environmental issues. Each category of environmental requirements was further characterized by identifying major functional dependencies with other system requirements and the relative significance of each class of requirements in influencing design and management decisions.

Cost requirements were organized into four stakeholder categories: (1) OEM, (2) consumer,
(3) EOL vehicle manager, and (4) externality costs borne by society. Performance requirements were organized according to the three product-system components defined by Keoleian and colleagues (1995): (1) product, (2) process, and (3) distribution. This method for characterizing environmental, cost, and performance requirements provides an effective means of evaluating interactions and conflicts among the major system requirements.

\section{Results}

\section{Life-Cycle Inventory}

The first step in assessing opportunities for environmental improvement of the IP was to characterize the environmental profile of an existing IP system. The life-cycle energy and lifecycle solid waste distributions for the IP of a generic midsized vehicle are presented in figure 3. Figures 4,5 , and 6 show the life-cycle emissions/releases of air pollutants, $\mathrm{CO}_{2}$, and water pollutants, respectively.

\section{Energy}

A total of 7,600 megajoules (MJ) of energy is consumed over the IP life cycle based on a vehicle life of $193,000 \mathrm{~km}$. The use phase, with $4,300 \mathrm{MJ}$ consumed, is responsible for $57 \%$ of the total life-cycle energy consumption. This result can be contrasted with the total vehicle lifecycle energy profile, in which the use phase accounts for about $90 \%$ of the total (Keoleian and $\mathrm{Kar} 1998$ ). There are two primary explanations for this difference. First, and most important, the allocation of the total vehicle energy to the IP only accounts for the direct effect of its mass on fuel consumption. The effect of aerodynamic drag losses on total vehicle fuel consumption are not allocated to the IP. Second, the difference in the material composition of the IP relative to the total vehicle results in differences between the materials production energy for the IP and the total vehicle. The IP consists of a greater fraction of plastic parts relative to the total vehicle. The material production energy for plastic resins is, in general, greater than twice as high as steel, the predominant material in the total vehicle (Sullivan and $\mathrm{Hu}$ 1995). 
Figure 3 Life-cycle energy consumption (in megajoules per IP) and solid waste (in kilograms per $(P)$ for the instrument panel of a generic midsized vehicle circa 1996.
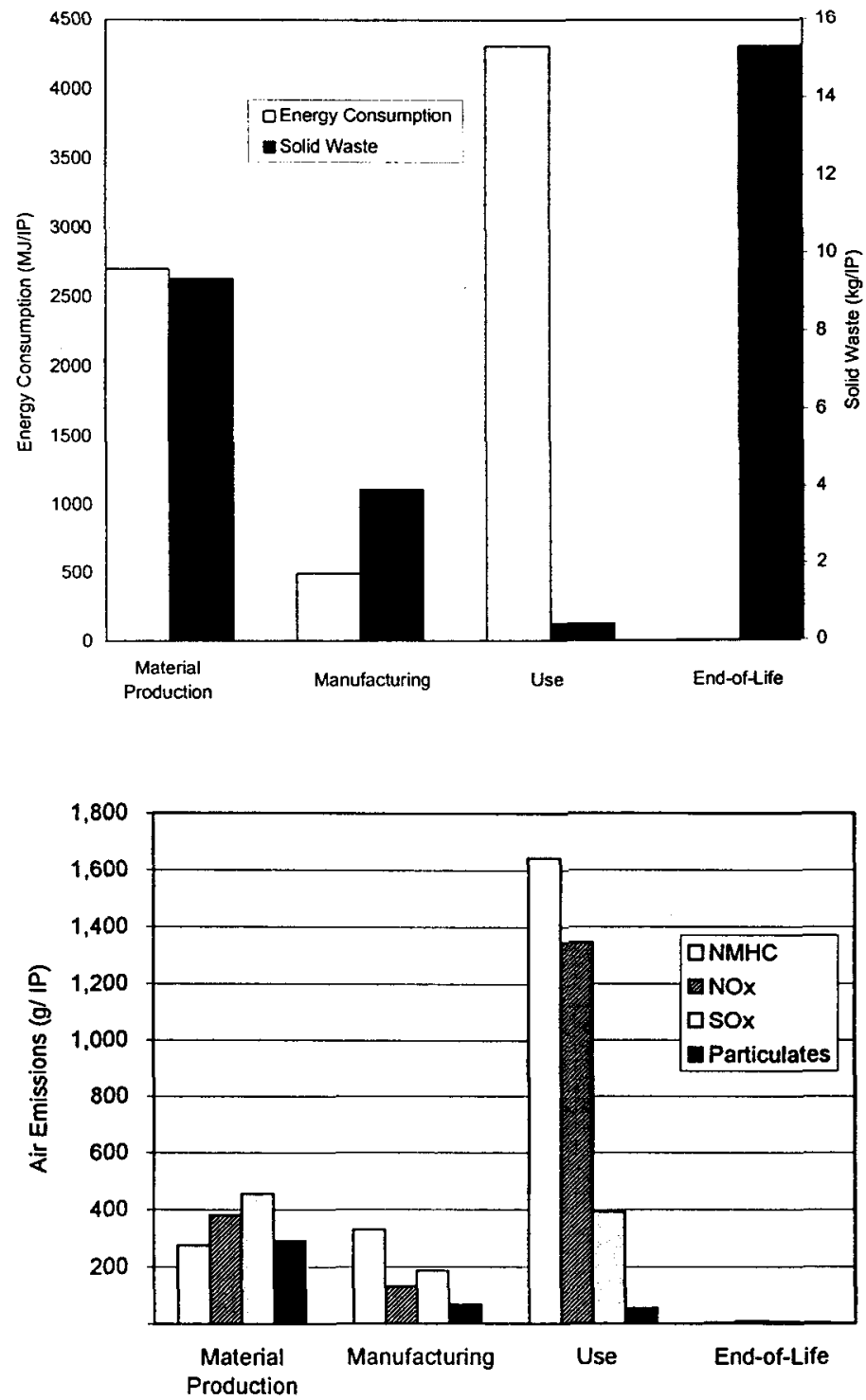

\section{Solid Waste}

The total life-cycle solid waste generation related to the IP was $29 \mathrm{~kg}$. Life-cycle solid waste has a different distribution across the life-cycle stages than does energy consumption. The majority of solid waste $(15.3 \mathrm{~kg}, 53 \%$ of the total) can be attributed to plastic components disposed in landfill during the EOL phase. Although both ferrous and nonferrous metal components are recycled, most plastic parts currently become part of the landfilled automotive shredder residue (ASR). The material production phase also yielded a substantial quantity $(32 \%)$ of the solid waste. Over half $(52 \%)$ of the solid waste from the material production stage was attributed to steel.

\section{Air Pollutant Emissions}

The life-cycle air pollutant emissions are shown in figures 4 and 5 . Vehicle emissions in the use phase are responsible for a large fraction of the life-cycle air pollutant emissions of carbon monoxide $(\mathrm{CO})$, methane $\left(\mathrm{CH}_{4}\right)$, nonmethane hydrocarbons (NMHC), nitrous oxides $\left(\mathrm{NO}_{x}\right)$, sulfur oxides $\left(\mathrm{SO}_{\mathrm{x}}\right)$, and particulates as indicated in figure 4 . The most energy-intensive life-cycle stages are responsible for a majority of 

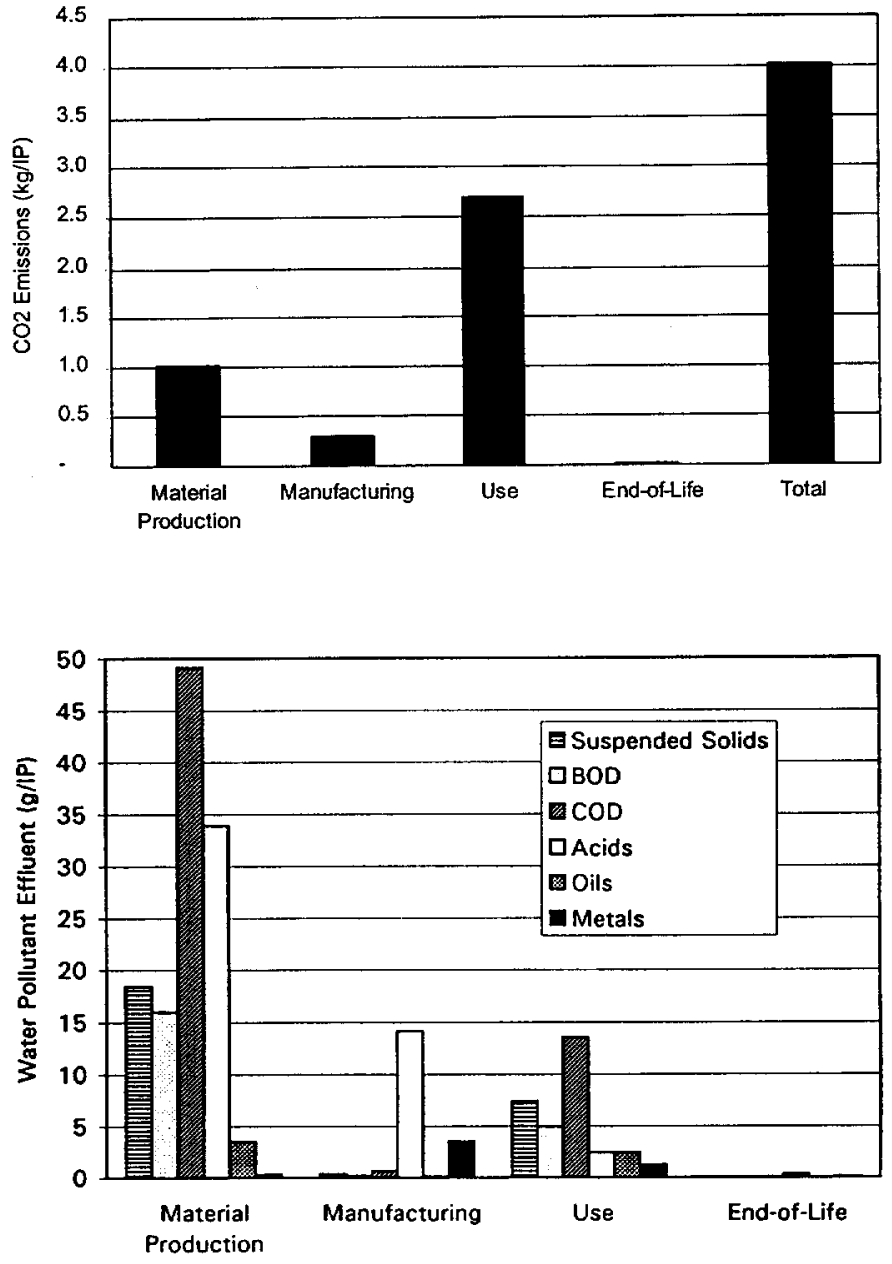

Figure 5 Life-cycle $\mathrm{CO}_{2}$ emissions for the instrument panel of a generic midsized vehicle circa 1996.
Figure 6 Life-cycle water pollutant effluents for the instrument panel of a generic midsized vehicle circa 1996. the $\mathrm{CO}_{2}$ releases, because $\mathrm{CO}_{2}$ is a combustion by-product. It has been reported elsewhere (McDaniel 1997) that the material production and use phases for IPs combined account for $93 \%$ of the $\mathrm{CO}_{2}$ emissions and, indeed, a very strong correlation exists between the energy consumption profile (figure 3 ) and the $\mathrm{CO}_{2}$ emissions (figure 5).

The NMHC emissions for the manufacturing stage indicated in figure 4 include uncontrolled VOC emissions associated with solvent-based clear/colorcoat painting. (The colorcoat is the base coat that includes pigment; the clearcoat is applied on top of the colorcoat for additional protection and finish). Solvent-based clear/ colorcoat painting of the IP generates $256 \mathrm{~g}$ of VOC/IP in addition to $72 \mathrm{~g}$ of NMHC/IP fuel- related emissions (NPPC 1997). Water-based colorcoat painting generates only $20 \mathrm{~g}$ additional VOC/IP (NPPC 1997). These quantities do not necessarily represent $V O C$ releases from the IP manufacturing facility. For example, these VOCs may be combusted in a thermal oxidizer with a high efficiency of destruction but an increase in $\mathrm{CO}_{2}$ emissions.

\section{Water Pollutant Effluents}

The life-cycle water pollutant effluents are shown in figure 6 . Generally, most of these effluents were released during the material production phase; however, the water effluent profile is incomplete because of the unavailability of manufacturing and shredding process-related water effluent data (only fuel-related water efflu- 
ents are shown for these two stages). The lifecycle dissolved solid releases $(1.3 \mathrm{~kg} / \mathrm{IP})$ were not shown in figure 6 because of their relative magnitude. Of the processes included in this study, the production of petroleum fuels released the highest amount of dissolved solids. Therefore, the use phase caused the greatest release of dissolved solids $(75 \%)$ because the majority of petroleum fuel consumption occurred during this stage. Suspended solids, chemical oxygen demand (COD), biological oxygen demand (BOD), acids, and oils were released predominantly during the material production stage; however, incorporation of manufacturing process-related releases (not available for this investigation) may lead to a significantly different life-cycle water-pollutant profile. The relatively high metals releases in the manufacturing stage are related to electricity consumption.

\section{Life-Cycle Costs}

Life-cycle costs are distributed among manufacturers, consumers, and EOL managers. The only available information related to the manufacturing cost of the IP was the average replacement part cost which represents a marked-up price. The replacement part cost is an upper limit for the manufacturing cost of the IP. The average replacement part cost for the three vehicle models investigated was $\$ 696$. A rough estimate of the actual IP manufacturing cost can be calculated by dividing the replacement part cost by a factor of six (\$116) (Kar and Keoleian 1996). (This approximation was provided by an OEM product design engineer for another automotive part, an air intake manifold.) Use phase operating costs to the consumer are $\$ 31.59$, based on the use of 102 liters (27 gallons) of gasoline consumed in transporting the IP $193,000 \mathrm{~km}$ $(120,000$ miles). The cost of shredding and processing the IP in the EOL stage was estimated to be $\$ 2.75$, including $\$ 1.25$ for landfill disposal of plastic waste. The salvage value of $\$ 3.47$ for magnesium and $\$ 0.96$ for steel implies a $\$ 1.68$ net credit for EOL management of the IP. There is not a strong correlation between life-cycle costs and life-cycle environmental burdens. For example, whereas use phase energy dominates the total life-cycle energy consumption, total gaso- line costs during the use phase are relatively small compared to the manufacturing costs.

\section{Multicriteria Analysis}

Performance, cost, and environmental requirements for an IP system are characterized in tables 1,2 , and 3 .

\section{Performance Requirements}

The performance requirements specify the functions of a product system. The product functional requirements are among the most significant "must" requirements influencing the overall success of an IP. Manufacturing process requirements that affect the product's function are equally important. As shown in table $1, \mathrm{IPs}$ must meet a wide range of demanding objectives. IPs perform numerous functions, ranging from supporting instrument clusters to protecting passengers and contributing to an aesthetically pleasing vehicle interior. Some of the more demanding performance requirements indicated in table 1 are to absorb crash energy; minimize vibration; minimize veiling glare; maximize recovery from indentarion; maximize HVAC performance and provide adjustable airflow; protect passengers at high, normal, and low temperatures; and minimize product development cycle time. The large set of use phase requirements in conjunction with the cost requirements highly constrain the design of the IP product system. Many of these performance requirements strongly influence material selection for IP parts and components, and environmental impacts are directly linked with each material choice.

\section{Cost Requirements}

Successful product systems must be economically competitive, and cost requirements often dominate decision making by manufacturers. Table 2 provides a characterization of the cost requirements for OEMs, consumers, and EOL managers. From an OEM perspective, the costs incurred by customers and EOL managers are not as important as manufacturing costs in the design decision-making process. In addition, a large set of environmental burdens are not represented directly in the market system. These externalities are responsible for a significant dis- 
Table I Characterization of performance requirements for an instrument panel

\begin{tabular}{|c|c|c|c|}
\hline $\begin{array}{l}\text { Type of performance } \\
\text { requirement }\end{array}$ & $\begin{array}{l}\text { Specific } \\
\text { examples }\end{array}$ & $\begin{array}{l}\text { Functional } \\
\text { relationships }\end{array}$ & $\begin{array}{l}\text { Current } \\
\text { status }\end{array}$ \\
\hline $\begin{array}{l}\text { Optimize } \\
\text { manufacturing } \\
\text { performance }\end{array}$ & $\begin{array}{l}\text { - product development } \\
\text { cycle } \\
\text { - production and } \\
\text { assembly time } \\
\text { - ergonomic and safety } \\
\text { conditions }\end{array}$ & $\begin{array}{l}\text { Dependent on: } \\
\text { - product design } \\
\text { - } \mathrm{R} \& \mathrm{D} \\
\text { - best available process } \\
\text { technology } \\
\text { - economic constraints } \\
\text { (existing capital } \\
\text { investment, } \mathrm{R} \& \mathrm{D} \\
\text { investment) } \\
\text { - regulatory constraints }\end{array}$ & $\begin{array}{l}\text { Manufacturing } \\
\text { performance is a } \\
\text { primary factor in } \\
\text { design. }\end{array}$ \\
\hline $\begin{array}{l}\text { Optimize product } \\
\text { functional } \\
\text { performance }\end{array}$ & $\begin{array}{l}\text { Use phase functional } \\
\text { requirements: } \\
\text { - support IP components } \\
\text { - prevent squeaks, } \\
\text { ratrles, and buzz } \\
\text { - protect passengers at } \\
\text { high, normal, and low } \\
\text { temperatures } \\
\text { - maintain appearance } \\
\text { (color, gloss, no cracks) } \\
\text { - resist heat sagging/ } \\
\text { maintain dimensional } \\
\text { stability } \\
\text { - resist UV degradation } \\
\text { - maximize HVAC } \\
\text { performance and } \\
\text { provide adjustable } \\
\text { airflow } \\
\text { - maximize resistance } \\
\text { to chemicals } \\
\text { (including cleaners) } \\
\text { - resistance to } \\
\text { temperature and } \\
\text { humidity cycles } \\
\text { - resistance to abrasion } \\
\text { and scuffing } \\
\text { - maximize recovery } \\
\text { from indentation } \\
\text { - maximize ease of repair } \\
\text { - minimize veiling glare } \\
\text { - minimize contribution } \\
\text { to window fogging } \\
\text { - minimize vibration } \\
\text { - minimize objection- } \\
\text { able odors }\end{array}$ & $\begin{array}{l}\text { Dependent on: } \\
\text { - consumer preferences } \\
\text { - industry performance } \\
\text { standards } \\
\text { - R \& D } \\
\text { - best available product } \\
\text { technology } \\
\text { - cost constraints } \\
\text { affecting the type of } \\
\text { technology that can } \\
\text { be implemented }\end{array}$ & $\begin{array}{l}\text { Product functional } \\
\text { performance is a } \\
\text { primary factor in } \\
\text { design. }\end{array}$ \\
\hline
\end{tabular}


Table 2 Characterization of cost requirements for an instrument panel

\begin{tabular}{|c|c|c|c|}
\hline $\begin{array}{l}\text { Type of cost } \\
\text { requirement }\end{array}$ & $\begin{array}{l}\text { Specific } \\
\text { examples }\end{array}$ & $\begin{array}{l}\text { Functional } \\
\text { relationships }\end{array}$ & $\begin{array}{l}\text { Current } \\
\text { status }\end{array}$ \\
\hline $\begin{array}{l}\text { Minimize manufacturer } \\
\text { costs }\end{array}$ & $\begin{array}{l}\text { - production and } \\
\text { tooling costs } \\
\text { - variable costs } \\
\text { (materials, labor, } \\
\text { utilities) } \\
\text { - warranty costs }\end{array}$ & $\begin{array}{l}\text { Dependent on: } \\
\text { - process design } \\
\text { (material and energy } \\
\text { efficiency, type and } \\
\text { quantity of wastes and } \\
\text { emissions) } \\
\text { - product complexity } \\
\text { - market conditions } \\
\text { (resource scarcity, } \\
\text { demand, and availabil- } \\
\text { ity of labor and capital) } \\
\text { - robustness and } \\
\text { reliability of design } \\
\text { - the managerial } \\
\text { accounting system }\end{array}$ & $\begin{array}{l}\text { Manufacturer costs } \\
\text { are a primary } \\
\text { determinant in } \\
\text { product design } \\
\text { decisions. }\end{array}$ \\
\hline Minimize customer costs & $\begin{array}{l}\text { - purchase price } \\
\text { - fuel costs } \\
\text { - maintenance and } \\
\text { replacement costs }\end{array}$ & $\begin{array}{l}\text { Dependent on: } \\
\text { - manufacturer costs } \\
\text { - vehicle fuel economy } \\
\text { - part weight } \\
\text { - gasoline price }\end{array}$ & $\begin{array}{l}\text { Vehicle price is a } \\
\text { key parameter in } \\
\text { consumer purchas- } \\
\text { ing. Relatively low } \\
\text { fuel costs have } \\
\text { limited impact on } \\
\text { consumer purchases. }\end{array}$ \\
\hline $\begin{array}{l}\text { Minimize end-of-life } \\
\text { managers' costs }\end{array}$ & $\begin{array}{l}\text { - capital, operating } \\
\text { (labor, separation, } \\
\text { and disposal) } \\
\text { - maximize value of } \\
\text { recovered materials } \\
\text { and parts }\end{array}$ & $\begin{array}{l}\text { Dependent on: } \\
\text { - vehicle design and } \\
\text { composition } \\
\text { - separation technology } \\
\text { and infrastructure } \\
\text { - salvage value of } \\
\text { secondary materials } \\
\text { (related to scarcity and } \\
\text { demand for primary } \\
\text { materials) }\end{array}$ & $\begin{array}{l}\text { High labor costs as } \\
\text { well as low landfill } \\
\text { disposal costs limit } \\
\text { further dismantling } \\
\text { and material } \\
\text { separation. }\end{array}$ \\
\hline $\begin{array}{l}\text { Minimize externality } \\
\text { (societal) costs }\end{array}$ & $\begin{array}{l}\text { - greenhouse gas } \\
\text { emissions } \\
\text { - Use phase } \mathrm{NO}_{x} \\
\text { VOC, and particu- } \\
\text { late emissions }\end{array}$ & $\begin{array}{l}\text { Dependent on: } \\
\text { - effectiveness of } \\
\text { corporate and govern- } \\
\text { mental policies in } \\
\text { internalizing these } \\
\text { costs } \\
\text { - methods of environ- } \\
\text { mental impact } \\
\text { valuation }\end{array}$ & $\begin{array}{l}\text { These costs receive } \\
\text { limited attention } \\
\text { because they are not } \\
\text { directly accounted } \\
\text { for in the market. }\end{array}$ \\
\hline
\end{tabular}


Table 3 Characterization of environmental requirements for an instrument panel

\begin{tabular}{|c|c|c|c|}
\hline $\begin{array}{l}\text { Type of environmenta } \\
\text { requirement }\end{array}$ & $\begin{array}{l}\text { Specific } \\
\text { examples }\end{array}$ & $\begin{array}{l}\text { Functional } \\
\text { relationships }\end{array}$ & $\begin{array}{l}\text { Current } \\
\text { status }\end{array}$ \\
\hline $\begin{array}{l}\text { Minimize the } \\
\text { following life-cycle } \\
\text { impacts (applicable } \\
\text { to each stage) }\end{array}$ & $\begin{array}{l}\text { - resource depletion } \\
\text { - ecology health effects } \\
\text { - human health effects } \\
\text { - social welfare }\end{array}$ & $\begin{array}{l}\text { A consequence of } \\
\text { inventory flows related } \\
\text { to the product system }\end{array}$ & $\begin{array}{l}\text { Methodology is not } \\
\text { standardized and } \\
\text { generally not used in } \\
\text { design and management } \\
\text { decisions. }\end{array}$ \\
\hline $\begin{array}{l}\text { Minimize the } \\
\text { following life-cycle } \\
\text { inventory burdens } \\
\text { (applicable to each } \\
\text { stage) }\end{array}$ & $\begin{array}{l}\text { - inputs: material and } \\
\text { energy } \\
\text { - outputs: air pollutant } \\
\text { emissions, water pollutant } \\
\text { discharges, solid wastes }\end{array}$ & $\begin{array}{l}\text { A consequence of the } \\
\text { design and manage- } \\
\text { ment of the product } \\
\text { system (including } \\
\text { corporate and } \\
\text { government environ- } \\
\text { mental policies) }\end{array}$ & $\begin{array}{l}\text { Currently used on a } \\
\text { very limited basis to } \\
\text { guide design and } \\
\text { management decisions. }\end{array}$ \\
\hline $\begin{array}{l}\text { Meet OEM internal } \\
\text { guidelines/strategies } \\
\text { that address discrete } \\
\text { life-cycle stages }\end{array}$ & $\begin{array}{l}\text { - substance use restrictions } \\
\text { (Chrysler CS90003, Ford } \\
\text { WSS-M99P9999-A1, GM } \\
\text { GM1000M) } \\
\text { - vehicle recycling guide- } \\
\text { lines } \\
\text { - vehicle fuel economy } \\
\text { targets } \\
\text { - manufacturing waste } \\
\text { minimization goals }\end{array}$ & $\begin{array}{l}\text { Developed to address } \\
\text { environmental issues } \\
\text { and regulations, and } \\
\text { enhance economic } \\
\text { performance }\end{array}$ & $\begin{array}{l}\text { Weighing of require- } \\
\text { ments varies from } \\
\text { "must" (substance use } \\
\text { restrictions) to "want" } \\
\text { (targets for recycled } \\
\text { content). }\end{array}$ \\
\hline $\begin{array}{l}\text { Meet external } \\
\text { requirements: } \\
\text { regulations }\end{array}$ & $\begin{array}{l}\text { - U.S. federal: OSHA, EPA, } \\
\text { (CAA, CWA, CERCLA, } \\
\text { SARA III, RCRA) } \\
\text { - CAFE } \\
\text { - European: proposed } \\
\text { guidelines for end-of-life } \\
\text { vehicle waste } \\
\text { - state and local regulations }\end{array}$ & $\begin{array}{l}\text { Developed to protect } \\
\text { human and ecological } \\
\text { health, and conserve } \\
\text { resources }\end{array}$ & $\begin{array}{l}\text { Statutory requirements } \\
\text { that must be met. }\end{array}$ \\
\hline $\begin{array}{l}\text { Meet external } \\
\text { requirements: } \\
\text { industrial standards, } \\
\text { voluntary programs }\end{array}$ & $\begin{array}{l}\text { - FMVSS (103-window } \\
\text { defroster, 107-reflecting } \\
\text { surfaces, 201, 204, and } \\
\text { 208-occupant crash } \\
\text { protection, 302- } \\
\text { flammability) } \\
\text { - SAE (J287-hand control } \\
\text { reach, J1050a-driver's } \\
\text { field of view, J1138- } \\
\text { controls location and } \\
\text { identification, J1344- } \\
\text { plastic part identification) } \\
\text { - ISO ( } 2575 \text {-symbols, } \\
\text { colors, and identification, } \\
4040-\text { location of } \\
\text { controls) }\end{array}$ & $\begin{array}{l}\text { Developed to ensure } \\
\text { driver and passenger } \\
\text { safety }\end{array}$ & $\begin{array}{l}\text { These voluntary } \\
\text { industry standards are } \\
\text { adopted by OEMs } \\
\text { (exception SAE } \\
\text { J1050a-driver's field of } \\
\text { view is mandatory). }\end{array}$ \\
\hline
\end{tabular}


connection between environmental objectives and the market forces that encourage effective design solutions to mitigate or eliminate environmental impacts.

\section{Environmental Requirements}

The environmental requirements indicated in table 3 can be ranked on two scales: their current feasibility for implementation and their reliability in leading to an environmentally optimal outcome. From a life-cycle perspective, environmental requirements seek to achieve ecologically sustainable product systems throughout materials production, manufacturing, use, and EOL management. Life-cycle impact assessment (LCIA) methodology serves to characterize and assess the environmental impacts associated with a product system in areas such as resource depletion, ecological health effects, and human health effects. Consequently, a "global" objective function can be defined that minimizes these impacts. Practical implementation, however, would require acceptable methods for measurement and valuation of incommensurable impact categories. Although the ultimate goal may be to apply LCIA in design, widespread application in the near future is not expected primarily because of limitations in the methodology.

Environmental impacts result from flows of materials, energy, and wastes. A more practical approach than LCIA to guiding design and management of the product system is to define a specific "global" objective function or alternatively a set of objective functions that minimize flows. This "less is better" approach, however, does not provide a basis for evaluating trade-offs among different inventory categories. This application of LCI to design is also currently limited by several factors including data availability, cost constraints, and excessive time requirements (Keoleian 1994). Given the elementary nature of LCI, $\mathrm{LCI}$ is less likely to determine the most environmentally preferable outcome compared to an LCIA-based design analysis.

Aside from consumers, OEMs play the greatest role in shaping the environmental profile of a product system. Thus their environmental management system (EMS) including environmental policies, goals, guidelines, performance measurements, and training is critical in influencing a product's environmental performance. The discrete design and management approaches do not necessarily lead to a globally optimum solution for minimizing environmental impact. Ultimately, an EMS operates in the context of external policies and market forces. The stakeholders in the IP's life cycle, especially the automobile manufacturers, must meet a wide variety of regulatory requirements. The total sum of federal, state, and local regulations forms a web of constraints that strongly influences each product system. This regulatory framework is also imperfect because of its single-media nature and focus on specific life-cycle activities (e.g., manufacturing or vehicle operation). In addition to regulations, OEMs can adopt a variety of industry standards or participate in voluntary programs that affect environmental, health, and safety performance. The Federal Motor Vehicle Safety Standards (FMVSS), International Standards Organization (ISO), and Society of Automotive Engineers (SAE) standards in table 3 (except SAE J1050a) are voluntary.

\section{Constraints on Improvement}

How constrained are design strategies for environmental improvement? Both the life-cycle inventory analysis results and the analysis of the IP requirements can be used to assess the feasibility and effectiveness of various strategies for improving the environmental profile of the IP. Various conflicts and trade-offs exist among the requirements that greatly influence opportunities for design improvements. Several strategies for reducing the most significant energy, emissions, and waste burdens highlighted in the inventory analysis are evaluated.

\section{Reducing Energy Consumption}

One strategy for reducing energy consumption in the use phase is to "lightweight" automotive components either by material substitution or by a reduction in material intensiveness. Various material substitutions involving steel, aluminum, magnesium, and plastic resins are possible for the IP system. However, the following performance requirements severely limit lightweighting options: 
1. provide support for airbags, components (e.g., radio), and steering column;

2. minimize vibration; and

3. meet FMVSS 201, 204, and 208-occupant crash protection.

For example, mass reductions for IP components may create difficulty in satisfying certain noise, vibration, and harshness requirements set by the OEM. While lightweighting decreases energy consumption during the use phase, the lighter materials such as primary aluminum and magnesium have significantly higher material production energies compared to steel.' Therefore, the energy saved by lightweighting during the use phase is partially offset by additional energy consumed during the material production phase. Aside from mandatory performance and regulatory requirements, cost is the most important determinant in the selection of materials, and, in general, the lighter weight materials are considerably more expensive than steel.

Reduction in life-cycle energy consumption for an IP is ultimately constrained by the fuel economy of the vehicle. The U.S. Corporate Average Fuel Economy (CAFE) standard for passenger cars has remained stagnant at 27.5 miles per gallon $(8.55 \mathrm{l} / 100 \mathrm{~km})$ since 1990 . Consequently, regulatory pressure for reducing fuel consumption is weak. Furthermore, relatively low gasoline prices provide a very weak incentive for consumers and manufacturers to reduce use phase energy consumption. Gasoline prices are still near historically low prices (inflation adjusted) (Keoleian et al. 1997).

\section{Reducing Air Pollutant Emissions}

Vehicle emissions are a predominant source of life-cycle air pollutant emissions. Exceptions are found for $\mathrm{SO}_{2}$ and particulates, where a majority of these emissions occur in the material production stage. The major sources of $\mathrm{SO}_{2}$ emissions in the material production stage are from polyurethane foam, which provides the cushion under the vinyl skin of the IP and steel which serves as a structural support. "Hardshell" IPs, a design alternative to the soft IPs found in midsized cars, do not require polyurethane. Hard-shell IPs, however, are considered a less aesthetically preferred option. Eliminating paint on the IP can be an effective strategy for reducing VOC releases from manufacturing. Both aesthetic requirements for color and the requirement for antiglare surfaces to minimize interference with driver and passenger vision (SAE J1050a-driver's field of view), however, must still be met. Adding in the pigment during vinyl sheet production is one method for reducing painting steps, but some difficulties can exist in color matching of components, such as doors and airbag compartments.

\section{Reducing Waste}

One strategy that may aid in the recovery of plastic components is to greatly reduce the number of plastic resins in IPs and thereby lower the separation and recovery costs. For example, a total of 15 different thermoplastic or thermoset materials were used in the instrument panels included in this study. The automotive recycling industry has not yet developed an economically viable method for separating and recovering these materials or parts. The salvage value of these materials and parts is insufficient to overcome relatively high labor costs for their removal. However, even if these costs are lowered, other significant changes in the current EOL infrastructure and cost accounting system are necessary to recover plastic components. For example, dismantlers are currently paid based on the total weight of the hulk, and thus have an economic disincentive to remove the instrument panel or other components (removing components decreases the weight of the hulk and thus lowers their "price per hulk"). Additionally, a variety of requirements limits the ability of manufacturers to use a fewer number of plastic materials. Specifically, the components in an IP must be able to (1) minimize veiling glare, (2) minimize vibration, (3) maximize recovery from indentation, (4) meet FMVSS 201, 204, and 208-occupant crash protection, (5) meet FMVSS 302-flammability, and (6) minimize material costs.

Given the wide array of requirements, the possibility of developing a satisfactory instrument panel from only one or a few plastic resins appears limited, but a recently developed model demonstrated that significant consolidations are possible. For example, the IPs in the 1996 Chrysler Dodge Dakota trucks are fabricated with large, 
structural thermoplastic beams that meet all performance requirements and reduce the overall IP part count by $10 \%$ (Chapman et al. 1996).

Even if fewer plastic material types are used, incentives to recover plastics and other automotive shredder residue constituent residues have been relatively weak. For example, the average landfill tipping fees in the United States are only $\$ 35 /$ metric ton ( $\$ 32 /$ ton), and many shredding companies have much lower rates (Repa and Blakey 1996). European Union guidelines for reducing the amount of EOL vehicle waste disposed in landfills have been established, which should force the automotive industry to address this issue. Targets are in place in Europe to reduce the amount of postconsumer vehicle waste from its current fraction of about $25 \%$ to $15 \%$ for all vehicles and $10 \%$ for new vehicles by 2002 , down to $5 \%$ by 2015 . The plastic content of the vehicle has been increasing steadily, making this goal potentially more difficult to realize.

\section{Conclusions}

From the perspective of the design engineer, environmental improvement of the IP system is highly constrained with respect to the existing set of system requirements and conditions. Multicriteria analysis demonstrates that a large and complex set of performance, cost, regulatory, and environmental requirements affect the design and management of the IP system. Although the use phase is responsible for a large fraction of the energy consumption and air emissions burden, inexpensive gasoline does not provide a strong incentive for increasing fuel economy. In addition, a total of 16 major performance requirements and twelve industry standards are applicable to the use phase alone. This set of industry performance requirements, combined with weak cost signals for energy and waste disposal, both technically and economically limit opportunities for improvement. Potentially significant improvements are feasible, however, if some of these system conditions are changed. Each of the stakeholders involved in the management of the automobile life cycle, including manufacturers, customers, and policymakers, has a role in shaping the system requirements and key system parameters.
A range of strategies for improvement were studied and their life-cycle implications considered. Eliminating polyurethane foam cushioning and IP painting could reduce burdens, but these measures would require significant changes in consumer preferences, and such changes are unlikely. Material substitutions are complicated because of inherent environmental trade-offs associated with alternative materials in automotive applications. Steel has a low material production energy and is easily recyclable, but it has a relatively high material production waste factor. Plastics, in general, have a much higher material production energy and are currently not recycled after the vehicle is shredded, but they generally have a low material production solid waste factor. Primary aluminum has a very high material production energy with a moderately high material production waste factor, but is also easily recyclable. The actual environmental burdens are dependent on the specific application because a different mass of material may be required to achieve functional equivalence (Young and Vanderburg 1994). Life-cycle assessment tools are necessary to elucidate the environmental trade-offs that generally arise from a material substitution. The limited access that design engineers have to LCA tools at present represents a resource constraint on achieving environmental improvements.

Although these conclusions may appear pessimistic, many opportunities exist for promoting environmental improvements. At a higher level in decision making, consumers provide the market demand for new vehicles. If their demand shifts to more fuel-efficient vehicles, the environmental burdens related to transporting the IP over the life of the vehicle decrease accordingly. This opportunity lies outside the direct scope of the design engineer. It is the role of policymakers to provide incentives and disincentives for environmental improvements through CAFE, gasoline taxes, a greenhouse emissions policy, and other policies addressing upstream and downstream burdens. Without addressing these issues, programs such as the U.S. EPA's Common Sense Initiative (CSI) will have limited impact. Changes in high-level system requirements, such as a gasoline tax, force design engineers to weigh 
environmental requirements more comparably with existing performance and cost constraints. Until these stronger measures are taken, environmental improvements progress in a piecemeal and incremental manner as a result of the complex set of existing design constraints.

This article illustrates the interrelationships between environmental, cost, performance, and regulatory factors governing the design of an instrument panel from the perspective of a product design team. Trade-offs will always exist, but changing the boundary conditions can stimulate existing and new technological innovations that can lead to more optimal design solutions.

A major barrier toward significant improvement is that OEMs place more emphasis on reducing costs within their domain and discount costs upstream or downstream from manufacturing. Until the full externality costs associated with gasoline, vehicle emissions, and depletion of nonrenewable material resources are internalized in the market, it is highly unlikely that significant changes will take place.

\section{Acknowledgments}

Jeff McDaniel's master's thesis research was instrumental in providing inventory data and a compilation of IP performance requirements. The author greatly appreciates the participation of CSI Automotive Life-Cycle Management/ Supplier Partnership project team members in this investigation. Partial funding for this investigation was provided by the U.S. Environmental Protection Agency under Assistance Agreement number CR 822998-01-0 to the University of Michigan. Kenneth Stone is the project officer at the U.S. EPA National Risk Management Research Laboratory. The contents do not necessarily reflect the views and policies of the U.S. EPA. Mention of trade names or commercial products does not constitute endorsement or recommendation for use.

\section{Note}

1. For instance, the material production energy of magnesium is four times that of steel (Higuchi and Nakajima 1996).

\section{References}

AAMA (American Automobile Manufacturers Association). 1995. Motor vehicle facts and figures. Detroit, MI.

American Metal Market. 1996. American Metal Market. 19 July, 6.

Chapman, D., D. Evans, and J. Soncrant. 1996. Design advantages and benefits of the Chrysler $\mathrm{Da}$ kota fully integrated thermoplastic instrument panel. SAE Technical Paper Series no. 960398. Warrendale, PA: SAE International, 1-5.

Curran, M. A. 1996. Environmental life-cycle assessment. New York: McGraw-Hill.

DeCicco, J. and M. Delucchi. 1997. Transportation, energy, and environment: How far can technology take us? Washington, DC: American Council for an Energy-Efficient Economy.

Farrington, S. 1996. Textron. Personal communication. 9 August.

Graedel, T. E. and B. R. Allenby. 1998. Industrial ecology and the automobile. Upper Saddle River, NJ: Prentice-Hall.

Harsch, M., P. Eyerer, M. Finkbeiner, and K. Saur. 1997. Life-cycle engineering of automobile painting processes. SAE Technical Paper Series no. 971182 . Warrendale, PA: SAE International, 155-166.

Higuchi, K. and K. Nakajima. 1996. Closed loop recycling of magnesium PC housing. 1996 IEEE Symposium on Electronics and the Environment. Dallas, Texas, 6-8 May, 102-108.

Kar, K. and Keoleian, G. A. 1996. Application of lifecycle design to an intake manifold. SAE Technical Paper Series no. 960410. Warrendale, PA: SAE International, 1-16.

Keoleian, G. A. 1994. The application of life-cycle assessment to design. Joumal of Cleaner Production 1(3-4): 143-149.

Keoleian, G. A. 1995a. Life-cycle design criteria for engine oil filters: AlliedSignal case study. SAE Technical Paper Series no. 951849. Reprinted from Proceedings of the 1995 Total Life-Cycle Conference. Vienna, Austria. 16-19 October, 109-119.

Keoleian, G. A. 1995b. Pollution prevention through life-cycle design. Pollution Prevention Handbook, edited by H. M. Freeman. New York: McGrawHill, 253-292.

Keoleian, G. A. and K. Kar. 1998. Life-cycle design of air intake manifolds. Cincinnati, $\mathrm{OH}$ : National Risk Management Research Laboratory, Office of Research and Development, U.S. EPA, in press.

Keoleian, G. A. and D. Menerey. 1993. Life-cycle design guidance manual: Environmental requirements 
and the product system. Cincinnati, OH: Risk Reduction Engineering Laboratory, Office of Research and Development, U.S. EPA.

Keoleian, G. A. and J. S. McDaniel. 1997. Life-cycle design of instrument panels: A common sense approach. SAE International Congress and Exposition. Detroit, Michigan. 24 February. SAE Technical Paper Series no. 970695. Warrendale, PA: SAE International.

Keoleian, G. A., J. Koch, and D. Menerey. 1995. Lifecycle design framework and demonstration projects: Profiles of ATET and AlliedSignal. Cincinnati, $\mathrm{OH}$ : National Risk Management Research Laboratory, U.S. EPA.

Keoleian, G. A., K. Kar, M. Manion, and J. Bulkley. 1997. Industrial ecology of the automobile: A lifecycle perspective. Warrendale, PA: SAE International.

McDaniel, J. S. 1997. Application of life-cycle assessment and design tools to instrument panels: Analysis for the Common Sense Initiative pilot project. Master's thesis, University of Michigan, School of Natural Resources and Environment.

NPPC (National Pollution Prevention Center). 1997. Life-cycle inventory analysis of instrument panels: VOC emissions in manufacturing. Final subcommittee support document (March 27), prepared by the National Pollution Prevention Center, University of Michigan, for the U.S. EPA Common Sense Initiative Auto Manufacturing Sector Subcommittee, Life-Cycle Management/Supplier Partnership Project Team.

National Research Council. 1992. Automotive fuel economy: How far should we go? Committee on
Fuel Economy of Automobiles and Light Trucks, Energy Engineering Board, Commission on Engineering and Technical Systems, National Research Council. Washington, DC: National Academy Press.

Repa, E. W. and A. Blakey. 1996. Municipal solid waste disposal trends; 1996 update. Waste Age (May): 170-180.

SETAC (Society of Environmental Toxicology and Chemistry). 1993a. Workshop report-guidelines for life-cycle assessment: A code of practice. Sesimbra, Portugal. 31 March. Pensacola, FL.

SETAC. 1993b. A conceptual framework for life-cycle impact assessment. Pensacola, FL.

Sullivan, J. L. and J. Hu. 1995. Life-cycle energy analysis for automobiles. SAE Total Life Cycle Conference, Vienna, Austria. 16 October. SAE Technical Paper Series no. 951829. Warrendale, PA: SAE International.

U.S. EPA (U.S. Environmental Protection Agency). 1995. Life-cycle impact assessment: A conceptual framework, key issues, and summary of existing methods. EPA-452/R-95-002. Research Triangle Park, NC: Office of Air Quality, U.S. EPA.

Vigon, B. W., D. A. Tolle, B. W. Cornary, H. C. Latham, C. L. Harrison, T. L. Boguski, R. G. Hunt, and J. D. Sellers. 1993. Life-cycle assessment: inventory guidelines and principles. Cincinnati, OH: U.S. EPA Risk Reduction Engineering Laboratory.

Young, S. B. and W. H. Vanderburg. 1994. Applying environmental life-cycle analysis to materials. Journal of the Minerals, Metals, and Materials Society 46(4): 22-27. 